\title{
Özbekistan ve Kırgızistan'daki Anklav/Eksklav Alanlarının Çözüm Süreci
}

\author{
Alaeddin YALÇINKAYA ${ }^{1}$ ve Khusan ABIDZHANOV ${ }^{2}$
}

$\ddot{\mathrm{O} z}$

Devletin ülkesi, genellikle kara sınırı, nehir veya deniz kıyısı ile sınırlandığı halde birçok ülkenin diğer ülke sınırları dahilinde toprakları bulunmaktadır. Tarihi veya etnik kökenleri bulunabilen bu tür bölgeler, eski Sovyet cumhuriyetlerinde oldukça fazladır. Sovyetler Birliği'nin dağılmasından sonra bu tür bölgeler kapsamında, kendi ülkesi içindeki diğer ülkeye ait alanlar ile bu alanlarda yaşayıp diğer ülkenin vatandaşları konumundaki kişilerle ilgili, egemenlik ve kamu hizmetleri bağlamında ciddi sorunlar bulunmaktadır. Refah toplumun önemli bir aracı olarak gelişmiş ülkeler arasındaki entegrasyon yani sınırların anlamsızlaşması uygulamalarına karşın genellikle sömürgecilik döneminden kalan sınır, vatandaşlık gibi konular, komşular ile ilişkileri olumsuz etkilemektedir. 2020 şartlarında Özbekistan ve Kırgızistan'daki anklav/eksklav alanları ile başta Tacikistan'dakiler olmak üzere benzer düzenlemelerin barışç1l yollarla huzur, güven, refah ve işbirliğini güçlendirecek şekilde çözülmesi gerekmektedir. Bu tür uygulamaların günümüzde ciddi bir sorun oluşturmaması, gerek dış güçlerin provokasyonları gerekse diğer beklenmedik gelişmeler sonucu, ilişkilerin bozulmayacağını, hatta çatışmalara yol açmayacağını garanti edemez. Bu makalede Özbekistan ve Kırgızistan'daki anklav/eksklav alanları kapsamındaki uygulamalara ve bunlardan kaynaklanan sorunlara son vermek üzere iki ülke arasındaki mutabakat süreci ele alınmaktadır. Bu kapsamda gerek her iki ülkede gerekse diğer bölge ülkelerinde, refah ve huzurun tesisi ile karşılıklı güven ve işbirliği ilişkileri çerçevesinde Uluslararası Hukuk zemininde çözüm önerileri tartışılmaktadır.

Anahtar Kelimeler: Ülke sınırları, Anklav/Eksklav, Eski Sovyet Cumhuriyetleri, Sorun çözümü, Uluslararası hukuk

\section{Solution Process of Enclave/Exclave Areas in Uzbekistan and Kyrgyzstan}

\begin{abstract}
Although the country of state is usually limited by land border, many countries have lands within the borders of other countries. Such regions, which may have historical or ethnic origins, are abundant in the former Soviet republics. After the dissolutions of the Soviet Union, there are serious problems in the context of sovereignty and public services regarding the areas belonging to other countries within their own country and the people who live in these areas and became citizens of the other country. Integration process, the meaningless of the borders has become an important means of welfare society. However border and citizenship-like problems, which remain from the colonial period, affect the relations with neighbours negatively. In 2020 conditions, the enclave/exclave areas in Uzbekisan and Kyrgyzstan and similar regions, especially those in Tajickistan, need to be resolved peacefully, in a way that will strengthen peace, trust, prosperity and cooperation. Such areas may not be serious problem for today. However, as a result of provocations of foreign Powers and other unexpected developments, it can not to be guaranteed that areas will cause conflicts. This article first discusses the reconciliation process between the two countries to end current and potential problems. In this context, solutions are discussed on the basis of International Law within the framework of mutual trust.
\end{abstract}

Key Words: Borders of states, Enclave/exclave, Former Soviet Republics, Conflict Resolution, International law

\section{Atıf İçin / Please Cite As:}

Yalçınkaya, A. ve Abıdzhanov, K. (2020). Özbekistan ve Kırgızistan'daki Anklav/Eksklav alanlarının çözüm süreci. Manas Sosyal Araștirmalar Dergisi, 9(4), 2653-2667.

Geliş Tarihi / Received Date: 03.05.2020

Kabul Tarihi / Accepted Date: 25.06.2020

\footnotetext{
${ }^{1}$ Prof. Dr., Marmara Üniversitesi, Siyasal Bilgiler Fakültesi, alaeddinyalcinkaya@gmail.com ORCID: 0000-0001-5553-0314

2 Yüksek Lisans Öğrencisi, Marmara Üniversitesi, Uluslararası Politik Ekonomi

ORCID: 0000-0003-2016-7943
} 


\section{Giriş}

Her ne kadar aksine bazı gelişmeler yaşansa da günümüzde küreselleşme bütün dünyayı etkileyen bir süreç olarak ilerlemektedir. Özellikle ulaşım ve iletişim araçlarındaki gelişmeler, bazı devletlerin veya yöneticilerin küreselleşme karşıtı politikalarına başarı şansı vermemektedir. Bu bağlamda öncelikle gelişmiş ülkeler arasındaki entegrasyon veya vize muafiyeti uygulamaları sonucu siyasi sınırlar önemli ölçüde etkisini kaybetmiştir. Bu tür ülkeler arasındaki dünya bir anlamda büyük bir köy haline gelmiştir. Bununla beraber özellikle eski sömürge ülkeleri veya azgelişmiş ülkeler arasındaki bir takım sorunlar, normal şartlar altında pasaport, vize ve gümrük işlemleri kapsamındaki ilişkilerin dahi yürümemesine yol açmıştır. Öte yandan yine bağımsızlık öncesi siyasi iradenin belirlediği sınırlar, özellikli bölgeler ile bu kapsamdaki haklar ve yetkiler, bağımsızlık sonrasında ciddi egemenlik tartışmalarına yol açmıştır. Bu bağlamda sömürgecilik döneminden miras kalan tartışmalı sınırlar ve alanlar yüzünden birçok bağımsız ülke, iç çatışma veya istikrarsızlık yönündeki gelişmeler ile dış müdahalelere açık hale gelmiştir.

Devletin kurucu unsuru olarak ulus kavramı Fransız ihtilali sürecinde ortaya çıkmış ve devletlerin hanedanlık kimliğinden ulus-devlet şekline dönüşümünün temel unsuru olmuştur. Bu süreçte Batı Avrupa'da krallıklar yetkilerini halkın temsilcilerine bırakırken, ulus kavramı etnik bir kimlikten çok aynı kaderi paylaşan, daha önce aynı acılanı, sıkıntılanı yaşamış olan ve gelecekte de birlikte huzurlu ve müreffeh bir toplum olmayı ümit eden toplulukların birlikteliğini ifade etmiştir. Buna karşın eski sömürgelerde genellikle etnik köken, din, mezhep veya aşiret benzeri temellere dayanan uluslaştırma süreçleri, bağımsızlık sonrasında da iç çatışmalar yanında komşu devletlerle işbirliğini engelleyen kimlik sorununun temelini oluşturmuştur.

İhtilal dönemi ve sonrasında ulus devlet süreci, milletini arayan devlet ya da devletini arayan millet olarak düşünülebilir. Fransa'da daha çok güce dayanan bu kavram, zamanla sömürgeci imparatorluklar tarafindan azınlıklar veya zayıf toplumların sömürülme aracı olarak kullanılmıştır. Bir şekilde oluşturulan ulus-devlet sınırları, klasik devletler açısından diğerlerine karşı bir kale fonksiyonunu yerine getirmiştir. Küreselleşmenin ileri aşamalarında ise birçok gelişmiş devletler arasındaki sınır sadece varsayılan bir çizgiden ibaret kalmıştır. Bununla beraber egemenlik kapsamındaki yetki ve uygulamalar açısından bu çizgilerin hiçbir devlet tarafından keyfi bir şekilde ihlal edilemeyeceğine dair karşılıklı güven de tesis edilmiştir. Buna karşın eski sömürgelerin bağımsızlık sürecindeki anlaşmalar, yeni devletlerin sınırları ile diğerleriyle olan ilişkileri konusundaki düzenlemeler, önemli ölçüde etnik köken, egemenlik veya sınır sorunlarını sürekli canlı tutacak, zaman zaman sıcak çatışmalara zemin hazırlayacak şekilde hazırlanmıştır. Komşu devlet içinde kendisine ait egemenlik bölgesi uygulamaları bu konuda ilginç örneklerdendir.

Bir devletin sınırları içinde diğer bir devletin ülkesine ait toprak parçası, kapalı bir alan olarak kalıp, farklı nedenlerle zaman zaman anlaşmazlık veya çatışma sebebi olmuştur. Bu kapalı bölgelerde yaşayan halkın anavatanına ulaşması genellikle sıkıntılı ve sorunlu olmuştur. Anklav/eksklav olarak adlandırılan bu bölgeler kapsamındaki sorunların gündeme gelmesi, her zaman devletler arasında gerginlik nedeni olmuştur. Bu gerginlik bazen devletler arasında çatışmalarla sonuçlanmıştır. Bununla beraber anklav/eksklav kapsamındaki sorunların öncelikle ilgili ülkeler arasında çözülmesi, mevcut ve muhtemel birçok sorunların zeminlerinin ortadan kalkması demektir. Çözüm sürecinde hiçbir devletin kendi ülkesine ait olan bir bölgeyi başkasına vermemesi, bununla beraber birçok örneği olduğu gibi uzlaşılan bölgeler kapsamında toprak değişimi ile vatandaşlık ilişkileri kapsamında yumuşak geçiş süreci benzer çözümler söz konusu olabilir.

Bu makalede, öncelikle ulus-devletlerin ortaya çıkmasındaki tarihsel süreç özetlenmekte, bu bağlamda Uluslararası Hukuk kapsamında devletin ülkesi konusunda diğer devlet/devletler ile karşılıklı mutabakata dayanan toprak kazanma ve kaybetme usullerine temas edilmektedir. Devletin ülkesi kapsamında bir devlete ait diğer devletin içindeki anklav/eksklav bölgelerinin tanımı verilerek söz konusu uygulamalardan kaynaklanan sorunlara ve uyuşmazlıklara temas edilmektedir. Çarlık Rusya'sının Türkistan hanlıklarını işgali, yaklaşık yarım asır sürmüş, I. Dünya Savaşı ertesinde Çarlık rejiminin çökmesi ile bağımsız Türk devletleri kurulmuştur. Bolşeviklerin yeniden bölgeyi ele geçirmesi ile etnik grup, boy temelli ulus devletlerin oluşturulması ve sınırlarının belirlenmesinin neden olduğu kimlik sorunları da burada özetlenmektedir. Türkistan hanlıkları yerine boy temelli cumhuriyetlerin oluşturulması, Özbekistan ve Kırgızistan örneklerinde ele alınmakta, söz konusu devletlerin kuruluşu ve sınırlarının belirlenmesi sürecindeki yasal düzenlemeler, sözleşmeler ve uluslararası mutabakatlara temas edilmekte, nihayet bunların ülke toprakları ve sinırlarından kaynaklanan sorunlar özetlenmektedir. Bu kapsamda her iki devlette de yer alan anklav/eksklav alanları kapsamındaki sorunlar ile çözüm kapsamındaki gelişmelere 
temas edilmekte, öneriler sunulmaktadır. Özellikle azgelişmiş ülkeler arasında bu tür tarihi, kültürel veya hukuksal anlamı olmayan, eski egemen güçten miras kalan sorunlu bölgelerin bugün olmasa da gelecekte çatışmalara kadar varacak anlaşmazlıklara kaynaklık edeceği dikkate alınarak öncelikle ilgili tarafların mutabakatıyla bir an önce çözümü üzerinde durulmaktadır.

Belirtmek gerekir ki eski sömürge durumundaki azgelişmiş toplumlarda devletler arasındaki alan sorunları ve bunların çözümünü, geleneksel toplum-modern toplum bağlamında incelemek son derece yetersiz kalacaktır. Çünkü sorunun kaynağında aşağıda ele alınacağı üzere devletlerin tarihi gerçekleri veya toplumsal özellikleri bulunmamaktadır. Esasen tanım gereği bu gibi ülkeleri, Sovyetlerin geleneksel bağları yok etme ve eğitim politikaları sonucu modern devlet sınıfına koymak mümkündür. Buna karşın SSCB dönemi ulus devlet düzenlemelerinin bölge gerçeklerine aykırı olarak bir kısmı yapay boylara bağlanması, teorik çerçeve belirlemeyi son derece anlamsız hale getirmiştir. Esasen Uluslararası İlişkiler teorilerini eski sömürge coğrafyasında uygulama deneyimleri genellikle başarısızlıkla sonuçlanmıştır. Çünkü özellikle sömürgecilik sonrasında görünüşte bağımsız devletler, önemli ölçüde eski sömürgeci devletlerin çizdiği sınırlar veya miras bıraktığı sorunlarla uğraşmak zorunda kalmışlardır. Siyasi bağımsızlığa karşın ekonomik hatta askeri bağımlılı̆̆ın devam etmesi, yeni bağımsız devletlerin aktörlük vasfını tartışmalı hale getirmiştir. Bu şartlar altında karşılaşılan sorunların çözümünde lider veya toplumun geleneksellik veya modernlik gibi nitelikleri, siyasi kültür özellikleri veya politik tercihleri ötesinde içinde yaşanılan çevre şartları çok daha önem arz etmektedir (Waltz, 2015, s.78). Eski Sovyet cumhuriyetlerinin çeyrek asrı aşan bağımsızlıkları dikkate alınarak anklav/ekslav ile diğer sorunların, devletler arasında ilişkilerdeki etkisi ve önemi modern devlet ve geleneksel devlet özellikleri açısından inceleme konusu yapılabilir. Bu makalede ise, mevcut şartlar altında, sorunun Uluslararası Hukuk bağlamında komşularla dayanışma, barış ve işbirliği ile iyi niyet ilkeleri çerçevesinde çözümü ele alınmaktadır.

\section{Hukuki Düzenlemeler ve Sözleşmeler}

Çalışmada öncelikle ülke sınırları, toprak kazanma konusundaki Uluslararası Hukuk kaynakları ve bu kapsamdaki sözleşmeler ele alınacaktır. Makale konusu olan Anklav/Eksklav alanlarının tanımları verilerek örnek uygulamalara temas edilecektir. Kırgızistan ve Özbekistan'daki söz konusu bölgelerin oluşumunda yasal düzenlemeler ve uluslararası mutabakatlar incelenecek ve bu konuda İslam Kerimov sonras1 gelişmeler özetlenecektir. İki ülke arasındaki toprak değişimi çerçevesindeki gelişmeler de dikkate alınarak bugün için sorun olmasa da muhtemel çatışmaları önlemek üzere kalıcı çözüm usulleri önerilecektir.

\section{Ülke Sınırları, Ulus Devlet, Toprak Kazanma ve Kaybetme}

Devleti oluşturan üç temel unsur olup bunlar ülke (toprak), halk (vatandaş) ve egemenliktir. Başta "tanıma" olmak üzere diğer bazı unsurlar da önemli olduğu halde olmadığı durumlarda da devlet fonksiyonu yerine getirilebilmektedir. Bu bağlamda devlet "belirli bir toprak parçast üzerinde egemen olan belirli bir insan topluluğunun oluşturduğu varlkktrr." (Gözler, 2007, s.4). Tanımdan da anlaşılacağı üzere ülke (toprak) unsuru olmadan devletin varllğından söz etmek mümkün değildir. Bunun doğal sonucu olarak devlete ait olan toprak parçasının, sıradan bir arazi veya arsanın ötesinde manevi, hukuki veya kimlikle bağlantılı anlamı bulunmaktadır. Her bir toprak parçasının, ona egemen olan devlet ve bu devletin kurucu unsuru durumundaki halk açısından sübjektif bir anlamı olduğu halde söz konusu sınırlar dahilindeki egemenlik haklarını diğer devletlerin de kabul etmesi gereği dikkate alındığında objektif bir gerçek ortaya çıkmaktadır. Nitekim Duguit'e göre ülke devletin subjektif değil, objektif bir unsuru olup sosyal boyutu söz konusudur (Mirow, 2010, s. 211). Bu gerçekten hareketle devlet, ülkesinin coğrafi sınırları içerisinde bulunan bütün topraklar ile yeraltı kısmı, hava sahası, iç suları (nehirler ve göller), varsa deniz sınırları içinde egemendir.

Günümüz uluslararası sisteminde ülkesiz bir devletin varlığı kabul edilmediği gibi sınırları mutlak olmayan bir devlet ülkesinin de varllğı söz konusu değildir. Devletin sadece bir arazi parçası olması yeterli olmadığı gibi ülke sınırlarının nereye uzandığı, hangi bölgelerin bu sınırlar içinde olduğu son derece önemli olup ulusal olduğu kadar Uluslararası Hukuk konusudur. Bir devletin yetki alanını diğer devletlerden ayıran hudutların nereden başlayıp nerede bittiğinin de mutlak olarak bilinmesi, belirlenmesi gerekmektedir. (Göze, 1959, s. 13). Bu bağlamda ülkenin sınırlarının nereden başlayıp nerede bittiği tarihte olduğu kadar günümüzde de Uluslararası Hukukun başta gelen sorunlarındandır. Hiçbir devlet kendi sınırlarını diğer devlet aleyhine, o devletin onayı olmadan genişletemez. Bu bağlamda gerektiğinde ilgili devletler yeni anlaşmalarla sınırları değiş̧tirebilmekte veya uluslararası yargıya başvurmaktadır (Doğan, 2016, s. 378). Birçok savaşların da aynı toprak parçası üzerinde birden çok egemenlik iddiasından dolayı çıktığını belirtelim. Bir devletin tek taraflı irade beyanı yerine uluslararası antlaşmalarla belirlenen ülke sınırları, meşru bir hak ve yasal bir hudut olarak kabul edilir (Evans ve Newnham, 2007, s. 545). 
Bu bağlamda bir devlete ait olan alanın çeşitli hukuki yöntemlerle başka devletlere devrinin birçok örneği bulunmaktadır. Zamanaşımı, devir, terk ve katılma yöntemleri, barışçıl yollarla bir devlete ait toprağın başka devlete geçmesi kapsamındaki Uluslararası Hukuk yollarıdır (Gündüz, 2003, s. 256). Doğu Almanya'nın Federal Almanya'ya katılması, Rusya'ya ait Alaska bölgesinin para karşıllğı ABD'ye devri veya Türkiye ile İran arasında 1932 İtilafnamesi ve 1937 Antlaşması ile toprak takası bu kapsamdaki örneklerdendir (Doğan, 2016, s. 385).

\section{Anklav ve Eksklav Alanları}

Günlük konuşma dilinde anklav (enclave) ifadesinin değişik boyutları söz konusu olup çoğunluktan farklı sosyal, kültürel, siyasi ve ekonomik olguları tanımlamak için kullanılmaktadır. Bu anlamda mutlaka siyasi sınırları belirli, ayrı bir devletin bölgesi demek değildir. İçinde bulunduğu çevre veya toplumdan farklı olgu ve olaylar için de kullanılabilmektedir. Anklav, aynı zamanda bir varlk/entite olup onu çevreleyen bir bölge ya da dışındaki çevreden farklı olduğunu vurgulayan bir özelliği ifade etmektedir. Anklav kavramının uluslararası mutabakat metinlerinde belirlenen ilk kullanımı 1526 Madrid Antlaşması'nda görülmektedir. Bu kavramın diplomasi dilinde belirlenen ilk kullanımı Fransızcadadır ${ }^{3}$ (Demir, 2019, s. 11).

Eksklav (exclave) ise "siyasi olarak bağh olduğg ülkeye coğrafi açıdan bağh olmayan" yani bir ana ülkenin sınırları dışında kalan yönetimindeki bölgenin diğer başka bir yabancı ülke ya da ülkelerde bulunan toprak parçasıdır. Bu durumda aynı toprak parçası kendisini kuşatan ülke açısından anklav, fakat siyasi olarak bağlı olduğu ülke açısından eksklav olarak görülmektedir. Farklı bir ifade ile anklav ve eksklav, ülkesel parça bağlamında değerlendirilen herhangi bir coğrafi entite, anavatan konumundaki ülke açısından bir eksklav, kuşatan ülke ve milletlerarası toplum açısından anklav olarak kabul edilmektedir (Demir, 2013, s. 79). Örneğin tarihi ve kültürel boyutları olan Süleyman Şah türbesinin bulunduğu alan, Türkiye'nin eksklav1 olup, Suriye açısında ise burası anklav alan durumundadır. Bu kapsamda dünyada oldukça farklı uygulamalar olup örneğin Vatikan, İtalya açısından bir anklav olduğu halde herhangi bir ülke açısından eksklav değildir. Öte yandan Baltık kıyısında Polonya ve Litvanya arasındaki Kaliningrad bölgesi, Rusya Federasyonu'nun eksklavı olduğu halde herhangi bir ülkenin anklavı değildir. Bu gerçekler 1şığında anklav/eksklav ilgili devletin sıra dışı bir parçası ya da organı durumunda olup o bölgede yaşayanların vatandaşı olduğu ülkeye geçmeleri, vatandaşlık ilişkileri çerçevesindeki hizmetleri ve görevleri takip etmeleri durumunda başka ülke/ülkelerin topraklarından geçmeleri zorunludur.

\section{Ulus Devlet ve Sınırları, 1789-1880}

Devletin ülke sınırları kapsamında gümümüzdeki düzenlemeler önemli ölçüde Yeni Çağdaki gelişmelerin sonucudur. Ulus devletin ortaya çıkışı, Avrupa'da feodalitenin çökmesi sürecinde merkezi devlet yönetime geçiş aşamalarıla gerçekleşmiştir (Akınc1, 2012, s. 62). Fransız İhtilalinden sonra egemenlik kavramındaki değişim neticesinde ulus devlet anlayışı güçlenmiş, bu bağlamda ülke sınırlarının anlamı da önem kazanmaya başlamıştır (Ay ve Uçar, 2015, s. 201). Devletin niteliğindeki bu değişimlerden egemenlik de etkilenmiş, bu bağlamda egemenliğin sadece dâhili değil aynı zamanda hârici, yani başka devletler karşısındaki varllğı etkinlik kazanmıştır. Çağdaş devlet önemli ölçüde ulus devlet sürecinin ürünü olup bu kapsamda egemenlik, öncelikle bir devletin ülke sınırları içinde tek otorite olduğu ve diğer devletlerin bu sınırlar dâhilinde idari, adli, kanuni ya da askeri vb. bir etkinliği olamayacağı demektir. Sonuç olarak devlet, ülke sınırları içinde egemenliği kullanmaya yetkili tek bir idareye tâbi olan halktan oluşmaktadır (Kotan, 2016, s. 16-19).

Fransız İhtilalinin ortaya çıktığı şartlarda doğal sınır anlayışı önemli bir varsayımdır. Bir devletin sınırı, bulunduğu coğrafi mevkiin, o devlete verdiği çevre şartlarıyla bağlantılıdır. İhtilal döneminde yayınlanan İnsan ve Yurttaş Hakları Bildirisi de halkın kendi geleceğini belirlemesi, eşitlik, temsilcileri aracilığıyla egemenliği kullanma hakkı yanında mülkiyet hakkını da ilan etmiştir (Bilsel, 1940, s. 228-229). Bu süreçte imparatorluk rejiminden ulus devlete geçilirken, egemenliğin de hanedan aileden halka geçtiği kabul edilmektedir. Yeni dönemde nerede bir ulus niteliğini taşıyan halk ortaya çıkmıssa bir müddet sonra devletleşme aşamasına geçilmiştir ki bir bakıma bütün Avrupa bu süreçten etkilemiştir. Belirtmek gerekir ki Batı Avrupa'da önce ulus kimliği ortaya çıkıp bu kimliği paylaşan halk, ulus devletini kurduğu halde özellikle eski sömürgelerde önce devlet kurulmuş daha sonra ulus kimliği oluşturulmaya çalışılmıştır. Gerek bu tür devletlerin kuruluş süreci ve sınırları gerekse devleti oluşturan ulus kimliğinin nitelikleri konusunda eski sömürgeciler, son derece etkili olmuştur. Dolayısıyla Batı dışı uluslaşma süreçleri, genellikle yapay, dışardan empoze edilen bir oluşum olarak genellikle mevcut toplum katmanlarının tepkisini çekmiş, bunun

\footnotetext{
3 "terrain on territoire situe a l'interieur des terres d'un autre": bir başkasının topraklarında bulunan arazi veya bölge.
} 
sonucu olarak pek başarılı olamamışır. Fransız İhtilali ertesinde özellikle Napolyon'un Avrupa'yı nüfuzu altına alması üzerine Rusya, İngiltere, Prusya ile Fransa'daki geleneksel yapıyı savunanlar, Avrupa'nın eski sisteminin yeniden kurulması için 1815 Viyana Kongresi'nde Kutsal İttifak oluşturma girişiminde bulundularsa da başarılı olamadılar. Bununla beraber Avrupa'da da yeni bağımsız devletler ortaya çıktı ve mevcut devletler toprak kaybina uğradı (Dupuy, 1990, s. 13-15).

1870'lerde Almanya'nın kuruluş sürecine doğru Alman uluslaşmasının biraz farklı boyutu bulunmaktadır. Ulus kimliğinin daha köklü bir şekilde oluştuğu Almanların yaşadığı coğrafyada, feodal yapıdan miras kalan sorunlu ve çatışmacı, yer yer saldırgan bir şekle bürünen ulus devletleşme aşamaları yaşanmıştır. Bu bağlamda iç ve dış unsurların sınırlandırdığı süreçte etno-kültürel niteliklerin hakim olduğu bir yapı ortaya çıkmıştır (Özdemir ve Bakan, 2016, s. 20). Ancak bu süreç, bir dış gücün müdahalesi olmadan bölge halkları ve yöneticilerin kendi aralarında mutabakatıyla yürümüss ve günümüzdeki yapı ortaya çıkmıştır. Dolayısıyla federasyonu oluşturan sınırların belirleyicisi halk olduğundan bunun sorunsuz bir şekilde sürdürülmesi de mümkün olmuştur. 1815 Viyana Kongresi kararlarına karşın Avrupa'daki imparatorlukların parçalanması ve küçük devletlerin kurulması 19. yüzyıl boyunca devam etmiştir. Bu süreçte Avusturya'ya bağlı İtalya da Avrupa'nın diğer büyük güçlerinden yardım alarak kendi ulus devletini kurmuştur (Bilsel, 1940, s. 242).

Burada kısaca temas edildiği üzere ulus ve devlet kavramlarının doğduğu coğrafyada dahi her ülke veya halk açısından farklı süreçler söz konusudur. Feodalite enkazı üzerinde şekillenmiş imparatorlukların da dağılmasıyla ilk bakışta daha rasyonel ve tek düze gelişmeler beklenebilirdi. Ancak ortak medeniyet, yakın tarih tecrübeleri ve yaygın şekilde paylaşılan kültürel özelliklere karşın, farklılıklar siyasi oluşumlarda da kendini göstermiştir. Belirtmek gerekir ki batının yaşadığı feodaliteden farklı devlet ve toplum geleneği olan Orta Asya cumhuriyetlerinin de kendileri dışında hazırlanmış bir sürece veya şablona mahkum edilmeleri, ulus devletleşmede sorunlara yol açtı̆̆ gibi huzur, refah ve güvenlik kapsamındaki problemlerin de kaynağını oluşturmaktadır.

\section{Ülke Sınırları ve Uluslararası Hukuk}

18. yüzyll sonunda yaşanan devrimler sonucunda halkın egemenliği ve liberal düşüncelerle ulusçuluk kavramı gelişen toplumların bağımsızlık süreçleri 19. yüzyıl boyunca da devam etmiştir. Büyük ve güçlü imparatorluklara karşı ayaklanmalar ile Asya ve diğer kitalara yayılan savaşlar sonucunda imparatorluklar zayıflamış ve dağılma sürecine girmiştir. Yeni sömürgeler edinme, mevcut sömürgelerde etkinliğini sürdürme veya hammadde-pazar paylaşımından doğan rekabet sürecindeki savaşlar, milyonlarca insanın hayatına mal olduğu gibi sömürgeci güçlerin de zayıflamasına yol açmıştır. Yeni büyük savaşların çıkmasını engellemek üzere ulusların kendi geleceğini belirleme hakkı, özellikle I. Dünya Savaşı sonrasında daha fazla dillendirilmiş, nihayet bu husus, BM Şartı'nın 2/4 maddesinde şöyle düzenlenmiştir: "Teşkilatatı Üyeleri,

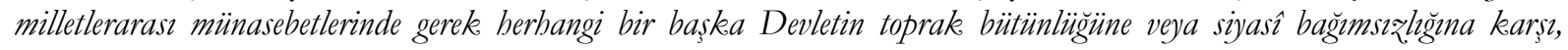
gerekse Birlesmis Milletlerin amaçlar ile telif edilemeyecek. herhangi bir suretle tehdide veya kuvvet kullanulmasina bassvurmaktan kaçmrlar:" (Gündüz, 2003, s. 87).

Sınırlar konusunda uzlaşmazlık veya belirli bir toprak parçası üzerinde birden fazla devletin egemenlik iddiası durumunda sorunun öncelikle BM Şartı hükümlerince çözüm yolları düzenlenmiştir. Viyana Antlaşmalar Hukuku Sözleşmesi ise devletler arasında önemli bir kısmı teamül kuralı olan hükümleri sözleşme haline getirmiştir. Bu sözleşme çerçevesinde iki veya daha fazla devlet, diğerleri yanında egemenlik ve sınır kapsamındaki konularda da istedikleri sözleşmeyi imzalayabilirler. Bununla beraber madde 35 antlaşmaya taraf olmayan, yani üçüncü taraf için diğer devletlerin bir yükümlülük getiremeyeceğini düzenlemektedir (Gündüz, 2003, s.193). Ancak saldırgan bir devlet söz konusu ise madde 75 'te düzenlendiği üzere gerekli tedbirler alınması gerekmektedir (Gündüz, 2003, s. 204).

Hudutların yeniden belirlenmesi ve kazanılan/kaybedilen topraklar üzerindeki halkların, başta vatandaşlık olmak üzere diğer halkların da karşıllklı hakları ve yükümlülükleri kapsamında birçok örnekler bulunmaktadır. Bunlar arasında Türkiye ve Yunanistan'ın Trakya bölgesi sınırları konusundaki 1913 Lozan ile yine aynı yıl imzalanan Londra antlaşmaları önem arz etmektedir. Nihayet 1923 Lozan Antlaşması ile bu çerçevede düzenlenen mübadele sözleşmesinin birçok açıdan örnek alınması gereken tarafları bulunmaktadir.

Öte yandan devler arasındaki hudut tespitinde ortaya çıkan uyuşmazlıklardan dolayı söz konusu tespitin hakemler tarafindan yapılması da Uluslararası Hukukun sunduğu, kısmen işaret edilen sözleşmelerde düzenlenmiş imkânlardandır. Örneğin 1931 ABD ile İngiltere arasındaki kuzey-batı sınırları 
ile 1869 Güney Afrika Cumhuriyeti ile Orange arasındaki sınır tespitleri, sorunun hakemler aracillğıyla çözümün örneklerindendir. Milletler Cemiyeti'nin kurucu antlaşması durumundaki cemiyet misakının 10. maddesi toprak bütünlügünü teminat altına alırken 12. madde ise hakem yolu dahil barışçıl çözüm yollarını düzenlemektedir. "Cemiyet üyeleri, aralarnda bir iliski kopmasina yol açma ibtimali olan herhangi bir uyusmąllk. çlkarsa bunu, ya tabkime, ya yargısal çözümleme usulüne ya da Konsey'in sorusturmasma havale etmeyi kabul ederler..." Bu bağlamda sınırların bir defa tespit edilmesinden sonra sabit kalmasının gereği üzerinde durulmakta ve bu sınırlarda ancak aralarında anlaşarak değişiklik yapabilecekleri de belirtilmektedir (Göze, 1959, s. 14-19).

\section{Orta Asya'da Ulus Devletler}

Tarihte Orta Asya veya İngilizce olarak Central Asia kavramı olmayıp hemen bütün Doğu ve Batı dillerinde Türkistan, Turkestan benzeri isimler kullanılmıştır. 20. yüzyıl başına kadar bütün Oryantalistler de bunu kullanmakta tereddüt etmemişlerdir. Bununla beraber Türkistan adlı bir hanlık veya devlet bilinmediği halde antik çağlardan günümüze bölgeyi kısmen veya tamamen yöneten birçok Türk devleti kurulmuştur. Rus Çarllğı, 1860'larda bölgeyi işgalden sonra Türkistan Umum Vilayeti'ni kurarak Türkistan ismini ilk defa siyasi birim olarak kullanmıştır. Buna karşın Bolşevik ihtilalinden sonra Türk boyları, coğrafi konumlarına göre farklı millet gibi kabul edilerek farklı özerk cumhuriyetlerin vatandaşları haline getirildi. Bu politikanın parçası olarak da her özerk cumhuriyet içerisinde yaşayan diğer boylara mensup olanlar için özerk bölgeler veya anklav/eksklav benzeri uygulamalar gündeme geldi.

$\mathrm{Bu}$ çalısmanın konusu olan anklav/eksklav uygulamalarının tarihi ve kültürel temeli olmayıp emperyalizmin temellerinden olan böl-yönet ilkesinin uygulamaya geçirilmesinin ilginç uygulamasını oluşturmaktadır. Halbuki tarihi gerçeklerin ortaya koyduğu gibi bu coğrafyaya adını veren Türkistan kavramı, aynı zamanda ortak bir kimlik sembolü haline gelmiştir. Bölge insanlarının milenyumlar boyunca iç içe, barış ve huzur içinde yaşadıkları, inanç ve kültür bakımından birbirlerine son derece yakın oldukları, en azından diğerinin kültür ve inancının çatışma veya ayrışma nedeni olmadığı bilinmektedir. (Yalçınkaya, 2006, s.15-26).

Türkistan kavramı ile boyların, aşiretlerin uluslaştırılma politikası arasındaki ilişkiler/çelişkiler son derece önemlidir. Bunu dikkate alarak Rus Türkolog Barthold'un uluslaştırma öncesi tespiti şöyledir: "Türkistan, Avrupa ve Asya kıtasmmn batı merkęî kısminda, büyük bir alam isgal eden, eskiden beri Turan veya Türkistan denilen memlekettir ki, bu da Türklerin yurdu demektir. Bu ülke, batıda Ural nebri ve Hazar denizi, doğuda Altay dağı ve Çin bududu yani Doğg Türkistan veya Kasgar'in doğu sinrlar, güneyde İran ve Afganistan, kuzeyde Tobol, Tomsk vilâyetleri [Sibirya] arasındadır." (Barthold, 1902, s. 174-204; Hayit, 1988, s. 23). Buna karşın Orta Asya kavramının daha çok iç Asya anlamında Türkistan'ı da içine alan Tibet, Moğolistan ile birlikte, zaman zaman kullanıldığı bilinmektedir (Yalçınkaya, 1997, s. 431-438).

Rus Çarlı̆̆ı, antik çağlardan beri ömrü üç-dört asrı bulan birçok Türk hanlığının yönettiği Türkistan coğrafyasını işgale başladığında bu coğrafyada Buhara, Hive, Hokand, Kaşgar hanlıkları ile Türkmen beylikleri bulunmaktaydı. Ignatiyev başkanlığındaki heyetin 1858 yllında bölgeye düzenlediği seyahat sonrasında hazırladığı rapor gereği, hanlıklar arasındaki uzlaşmazlık konuları kızıştırılacak, bu süreçte Çarlık yönetimi zayıf olan tarafı destekleyecek, böylece en az zayiatla bölge işgal edilecekti (Strong, 1975, s. 236260). Bu strateji esas alınarak Türkistan hanlıkları işgal edildi ve Rus yönetimi kuruldu. I. Dünya Savaşı'nda asker ihtiyacını karşılamak üzere Türklerin de askere alınma kararına karşın, aynı bölgeden askere alınan Ruslara ve ailelerine sunulan maddi desteğin Türklere verilmemesi üzerine 1916 olayları yaşanmıştır. Önemli ölçüde bu süreçteki çatışmalar sonucu olarak Rus Çarllğı 1917'de çökmüştür. Aynı yıl I. ve II. Umum Türkistan Milli Kurultayları oluşturulmuştur. Devletin şekli, sınırları, hukuk sistemi gibi birçok konuların ele alındığı bu kurultaylara bütün Türkistan coğrafyasından delegelerin katılmasıyla bir anlamda Almanların uluslaşmasına benzer bir süreç başlamıştır. Buna karşın Bolşeviklerin yönetimi ele geçirmesinden sonra Kızılordu, bölgeyi işgal etmiştir. (Usmonov, Sodıqov ve Burxonova, 2006, s. 5-16).

Bolşevikler, Moskova ve St. Petersburg gibi merkezleri ele geçirdikten sonra, Kafkasya ve Türkistan dahil Rus Çarlığı coğrafyasındaki diğer bölgeleri birkaç yıl içinde kontrol altına almıştır. (Rajabov ve Zamonov, 2016, s.11). İlginçtir ki I. Dünya Savaşı sonrasının yaygın uygulaması, imparatorluklar bünyesindeki halklara self determinasyon hakk1, eski Rus Çarlığı bölgesindeki Türklere ve diğer Rus olmayan halklara verilmemiştir. Bu bağlamda Wilson Prensiplerinin 6. Maddesine göre eski Çarlık toprakları üzerinde Bolşevik yönetiminin kurulması uygun bulunmuştur. 
Nisan-Mayıs 1918'de Taşkent'te düzenlenen 5. Sovyet Kongresi'nde Türkistan Bolşevik Özerk Devleti oluşturulmasına karar verilerek Rusya Federasyonu bünyesinde Türkistan Sovyet Özerk Cumhuriyeti kurulmuştur. Kuruluşun ilk aşamalarında tarihi ve kültürel değerlerin dikkate alınmasına karşın Türkistan devletinin yasama ve yürütme organlarının yapısı ve görevleri gibi konularda bu değerlere aykırı planlar uygulanmaya başlanmışır (Eşov, 2012). Belirtmek gerekir ki Sovyet dönemi tarih kitaplarında Türkistan halkının kendi isteği ile Bolşevik yönetimini kabul ettiği yazıldığı halde bu iddia bütünüyle gerçek dışıdır. Türkistan halkı 1916'dan itibaren hemen bütün şehirlerde Ruslara karşı bağımsızlık mücadelesi başlatmış, Ekim İhtilali ile başlayan iç savaş döneminde bölgesel devletler kurulmuştur. Kızılordu'nun Türkistan'ı işgali sürecinde de Basmacı Hareketi olarak bilinen birlikler halinde Bolşeviklerin ülkeyi ele geçirmesine karşı mücadele edilmiş, ancak işgal önlenememiştir (Usmonov, Sodiqov ve Burxonova, 2006, s. 18).

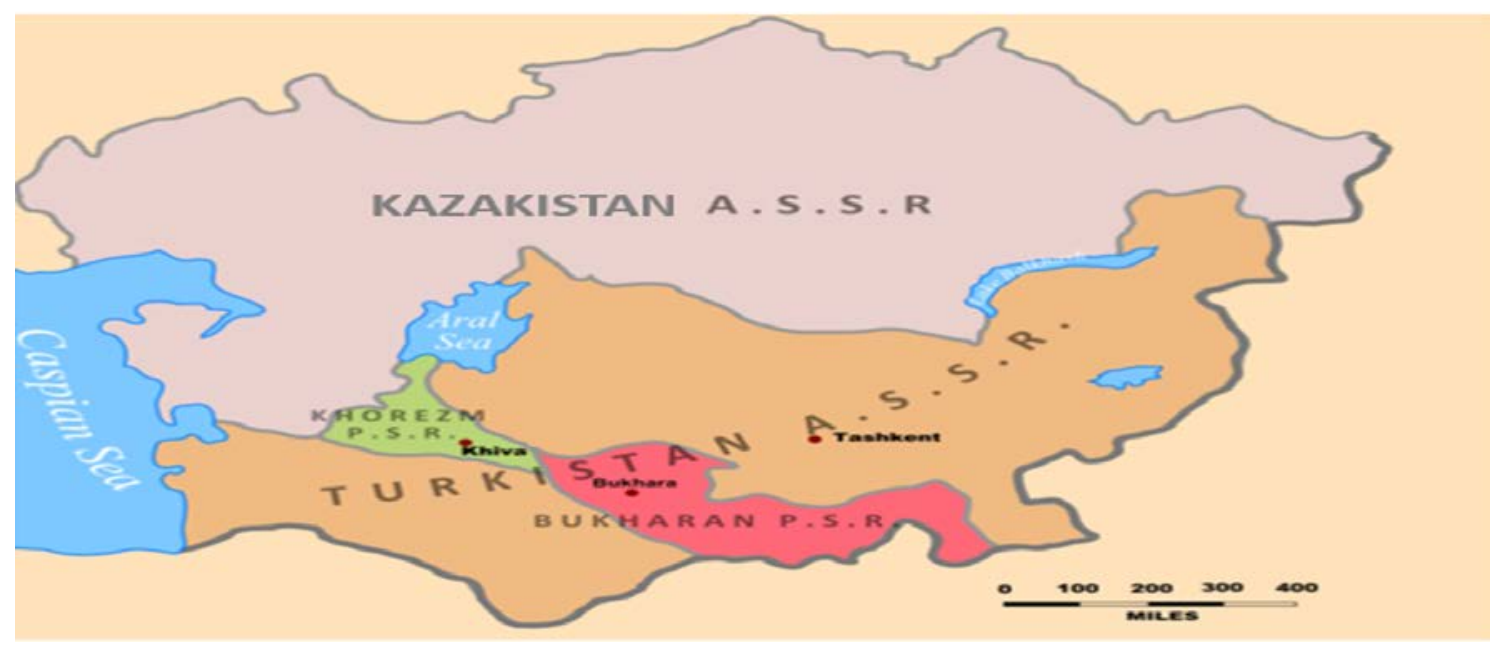

Harita 1. 1918 Sovyet Kongresi'ne göre Türkistan Özerk Sovyet Sosyalist Cumburiyeti (Eşov, 2012)

Belirtmek gerekir ki harita 1'de görüldüğü üzere 1918 Beşinci Sovyet Kongresi kararı gereği Buhara ve Harezm devletleri, Türkistan Özerk Sosyalist Cumhuriyeti dışında tutularak Türkistan, ortadan ikiye ayrılmıştı. Böylece Bolşeviklerin bölgeye müdahalesinin daha ilk aşamasında Türkistan devletini dört ayrı parçaya bölmüşlerdir. Buna karşın Nisan 1922'de önde gelen Türk temsilciler, Semerkant'ta Türkistan Müslümanları II. Kurultayı'nı toplayarak Türkistan'da Türk Müstakil İslam Cumhuriyeti'nin kurulması ve 36 maddeden oluşan geçici Anayasayı kabul ettiler. Her ne kadar o günkü şartlarda bu tür kararların uygulamada başarılı olma şansı çok zayıf ise de halkın iradesini yansıtma bakımından bu toplantı ve alınan kararlar son derece önemlidir. Nitekim bir müddet sonra kurultay gereği oluşturulan heyet dağıldı (Eşov, 2012).

Belirtmek gerekir ki Bolşevikler, Türkistan'daki yönetim birimlerinin oluşturulmasının her aşamasında Müslüman Türkleri daha kolay yönetmek için aynı kökten gelen aynı inancı ve kültürü paylaşan bu halklar içinde Özbekler, Türkmenler, Karakalpaklar, Kazaklar, Kırgızlar, Tacikler gibi etnik ayrım temelli idari yapılanmalara gitmeyi öncelikli prensip haline getirdiler. Hâlbuki batıdaki uluslaşma sürecinde farklılıklardan çok ortak yanlar dikkate alınarak birlikte, barış içinde yaşama ön planda tutulmuştu. Türkistan'daki her bir Türk boyu veya bölge halkı ayrı bir millet muamelesine tabi tutularak Fransız veya Alman uluslaşması sürecinde halkların kendi egemenliklerini kurma sürecindeki birleștirici unsurlar, bu bölgede ayrıştırmak ve çatışmaları sürekli kılmak üzere uygulandı (Rajabov ve Zamonov, 2017, s. 48).

27 Nisan 1920'de Hive'de yapılan I. Harezm Kurultayında Harezm Halk Sovyet Cumhuriyeti geçici anayasası kabul edildi. Ancak bu cumhuriyetin kendi temsilcileri tarafindan yönetilmesi engellendi. Ekim 1923 'te IV. Harezm Kurultayı ile Harezm Sovyet Sosyalist Cumhuriyeti (SSC) kuruldu. Benzer toplantlarla önce Buhara Halk Sovyet Cumhuriyeti, daha sonra Buhara SSC kuruldu (Usmonov ve Sadiqov, 2010, s. 56-69).

Türkistan coğrafyasında ulusal bölge sınırlarının oluşturulması için 5 Nisan 1924 Rusya Komünist Partisi tarafindan özel bir komisyon oluşturuldu (Usmonov, Sodiqov ve Burxonova, 2006, s. 282-283). 16 Eylül 1924'de ise Türkistan Özerk SSC Merkez Yönetim Komitesi'nin olağanüstü oturumunda Orta Asya ulus bölge sınırları oluşturulasına karar verildi. Birkaç gün sonra Buhara ve Harezm halk vekilleri de benzer karar aldılar. Buna göre Özbekistan SSC ve Türkmenistan SSC'nin kurulmasının yolu açıldı. Böylece daha 
önce kurulmuş olan Türkistan, Buhara ve Harezm yerine şu altı devletin kuruluş süreci başladı: Özbekistan SSC, buna bağlı Tacikistan Özerk SSC, Türkmenistan SSC, Kazakistan SSC, buna bağlı Karakalpakistan Özerk SSC ve Karakırgız Özerk SSC (Rajabov, Zamonov, 2017, s. 52). Sonuç olarak Türkistan coğrafyasında daha sonra yeni bölünme ve çatışma alanlarının da oluşturulacağı, aynı halkın farklı ulus devletler halinde parçalanmasının hedeflendiği suni sınırlarla devletler oluşumu başlatıldı. 1936 Sovyet Anayasasının getirdiği bazı değişikliklerle belirlenen ülkeler ve sınırları günümüze kadar devam etmektedir.

Belirtmek gerekir 2020 şartlarında diğer eski Sovyet cumhuriyetlerinde oluğu Kırg1zistan ve Özbekistan'da farklı Türk boylarına mensup halklar yanında Rus kökenli vatandaşlar da yaşamakta olup farklı etnik ve dini gruplardan olan kesimler arasında saygı ve hoşgörü temelli barış ve huzur ortamı kurulmuştur. Bununla beraber bölge halklarının tarihi ve kültürel gerçekleriyle ilgisiz olup her firsatta çatışma ve sorun kaynağ1 olabilecek olan anklav/eksklav benzeri tuzak bölgelerin oluşum sürecindeki emperyalist politikaların, çözüm sürecindeki iradeyi ortaya koymak için hatırlanması ve iyi tahlil edilmesi gerekmektedir. Tarihte kalmış olan söz konusu yanlış ve kötü amaçlı uygulamaların incelenmesi ve çözüm yoluna gidilmesiyle, devletler veya halklar arasında nefret ve düşmanlık amacindan ziyade gelecekteki refah ve güvenlik hedeflenmektedir.

\section{Özbekistan ve Kırgızistan Sınırları ile Anklav ve Eksklavlar}

\section{Özbekistan Sovyet Sosyalist Cumhuriyeti}

Özbekistan'ın bugünkü ulus-devlet sınırlarının oluşum süreci, yukarıda işaret edildiği gibi 1925'e kadar uzamaktadır. 13 Şubat 1925 'de Buhara'da toplanan I. Özbek Sovyet Kongresi, 17 Şubat'ta Özbekistan SSC'nin oluşturulması konusunda bir bildiri yayınlamıştır. Özbekistan SSC'nin ilk sınırları içinde Taşkent, Semerkant, Fergana, Kaşkaderya, Zarafşan, Surhanderya, Harezm vilayetleri yanında Tacikistan Özerk SSC de yer almıştır. İkinci bir sınır tespitindeki vilayetler ise Harezm, Buhara, Orta Zarafşan, Semerkant, Taşkent, Hoçent, Kokand, Andican, Surhanderya, Kaşkaderya ile Kazak-Karakalpak olarak belirlendi. 16 Ekim 1929 tarihinde Özbekistan SSC'ye bağlı Tacikistan ÖSSC, Özbekistan'dan bağımsız SSC haline getirildi. Daha önce Özbekistan sınırları içinde yer alan Hoçent ise Tacikistan SSC'ne verildi (Rajabov ve Zamonov, 2017, s. 53-59).

\section{Kırgızistan Sovyet Sosyalist Cumhuriyeti}

Öncelikle Sovyet cumhuriyetlerinin oluşum aşamasında Kırgızistan ve Kazakistan isimleri konusunda, daha sonra düzeltilmiş olan yanlış isimlendirmeyi hatırlamak gerek. Çarlık rejiminin yıkılması sürecinde kurulan Alaş Orda devletinin kaldırılmasından sonra 1920'de Kazakistan'da, Rusya Sovyet Federe Sosyalist Cumhuriyeti bünyesinde, Kırg1z Özerk Cumhuriyeti kurulmuştur. Bu dönemde Bolşevikler, Kazaklara Kırgız, Kırgızlara ise Kara Kırgız adını vermişlerdi. Geçen süre zarfında yanlış isimlendirmeler düzeltilmiş, 25 Mayıs 1936 SSCB Anayasası ile Kazakistan ve Kırgizistan ayr1 Sovyet cumhuriyetleri halinde anayasadaki yerini almışlardır (Yalçınkaya, 2004, s. 71).

Ocak 1924'de Komünist Partisi Merkez Komitesince, Orta Asya'da ulusal sınırların oluşturulması kararı alınd1. Merkez Komitesi'nin II. Kongresi kararı ile 14 Ekim 1924'de Rusya Federasyonu bünyesinde Kara-Kırg1z Özerk Bölgesi kuruldu. 25 Mayıs 1925'de ise Rusya Merkez Yönetim Komitesi tarafından alınan kararla Kara-Kırgız Özerk Bölgesi'nin ismi Kırgız Özerk Bölgesi olarak değiştirildi. Kırg1z Özerk Bölgesi'nin temsilcilerinin oluşturduğu kongrede Kırgızistan'ın SSC haline getirilmesi yönünde karar alındı. Bu karar doğrultusundaki talep SSCB merkez yönetimine gönderildi. SSCB Merkez yönetimi, 1 Şubat 1926 tarihinde bu talebi kabul etti ve böylece Kırgızistan SSC kurulmuş oldu. 25 Mayıs 1936 tarihli Sovyet Anayasası diğer cumhuriyetlerle birlikte Özbekistan SSC ve Kirg1zistan SSC'ne yer verdi. Kırg1zistan SSC'ni oluşturan alanlar, Karakol bölgesi, Bişkek, Evliya Ata'nın bir kısmı, Nemangan ile Andican'ın önemli kısımları, Fergana ve Hokand'ın bazı bölgeleri ile Oş ve Pamir'in kuzeyini kapsamaktaydı (Devlet, 1989, s. 194-200; İmankulov, 2014, s. 53-56).

\section{Özbekistan ve Kırgızistan'da Anklav/Eksklavlar}

Belirtmek gerekir ki ankklav/eksklav benzeri, Sovyet döneminden kalan sorun kaynağı alanlar sadece bu iki ülkede olmayıp başta Tacikistan olmak üzere diğer komşu devletler ve eski Sovyet cumhuriyetlerinde de bulunmaktadır. Bunların bir kısmı anklav/eksklav şeklinde olduğu gibi özerk cumhuriyet veya özerk bölgeler de sorun kaynağ1 olmaya devam etmektedir. Kafkas cumhuriyetlerinde bunların ilginç örnekleri bulunup Güney Osetya bunlar arasında en dikkat çekenlerdendir. Yukarıda da işaret edildiği gibi bu makalede sadece Özbekistan ve Kırgızistan'ın karşılıklı anklav ve ekslavları ele alınmaktadır. 
1991 sonunda SSCB'nin dağılmasıyla Orta Asya cumhuriyetleri de bağımsızlıklarını kazanmıştır. Özbekistan SSC ve Kırgızistan SSC 1991'de bağımsızlıklarını ilan ederek Özbekistan Cumhuriyeti ve Kırgızistan Cumhuriyet adlarıyla yeni devletler olarak kuruldular. İki sınır komşu olmanın ötesinde jeopolitik bakımdan iç içe geçmiş bu iki devlet, bağımsızlık sürecinde yeni antlaşmalar yaparak 1993'de aralarında diplomatik ilişki kurdular. 1996'da ise iki devlet arasında Ebedi Dostluk Antlaşması imzalandı. Böylece dostane ilişkileri geliştirmeyi, ekonomik işbirliğini ilerletmeyi ve toprak bütünlügünü korumayı ve güvence altına almayı sağlamaya çalıştılar. 2000'li yıllarda, iki komşu arasında sınırların kesin tespiti ve ölçümü çalsşmaları başladı. İki ülke arasındaki sınırlar $1379 \mathrm{~km}$ olduğu halde bunun sadece 1050 km'lik kısmı kesin olarak belirlenmiştir. (Kırgızistan ve Özbekistan, 2015).

Özbekistan ve Kırgizistan sınırları boyunca 70-100 arasında tartışmalı bölge olduğu tahmin edilmektedir. Bu kapsamdaki sorunları çözmek için iki ülke arasında 14 Ağustos 2014'de özel bir komisyon kurulmuştur: "Kırgız-Özbek Hükümetlerarası Devlet Sınırlarının Sınırlanması ve Sınırlandırılması Komisyonu" (İntergovernmental Commission On The Delimitation And Demarcation Of The State Border). Öte yandan iki ülkenin karşılıklı olarak toplam 5 anklav/eksklav alanları bulunmaktadır. ${ }^{4}$

Özbekistan'ın Kırgızistan'daki dört eksklavı Soh, Şahimerdan, Çon-Karakalça ve Taş-Tepe olup Kırgızistan'ın ise Özbekistan'da Barak eksklavı bulunmaktadır. Bunlardan yüzölçümü ve nüfus olarak Soh $350 \mathrm{~km}^{2}$ olup burada 50.000 'den fazla Özbekistan vatandaşı ikamet etmektedir. Şahimerdan ise 90 $\mathrm{km}^{2}$ olup 40.000 civarında nüfusa sahiptir. Kırgızistan'ın Barak eksklavının nüfusu 589 ile 1000 kişi arasındadır. Özbekistan, Kırgızistan ile toprak değişimi için antlaşma yaparak Soh anklavı Özbekistan'ın esas kara sınırı kısmına doğru geniş bir toprak şeridi ile ilhakı gündeme geldi. Bu süreçte Soh'un güney bölgesinin Kırgızistan'a bırakılması teklif edildi ancak Kırgız tarafi bunda bir çıkar göremediğinden mutabakattan vazgeçti. Bu durum iki ülke arasında gerginliğe yol açtı. Belirtmek gerekir ki kesinleşmeyen sinırlar ve anklav/eksklav sorunları konusunda resmi beyanlar iki ülke arasında gerginlik nedeni olmaktadır. (Orta Asya Jeopolitiği ve Ekonomisi, 2010, s.103).

Bu bölgelerin oluşum sürecine bakıldığında, SSCB'nin ilk yıllarına ulaşılmaktadır. 1925 yılında Özbekistan SSC ve Kara-Kırgız Özerk Bölgesi arasındaki sınırlar belirlenirken özellikle çözülemeyen, sorun kaynağı olacak bölgeler bırakılmıştır (Alamanov, 2018, s. 454). Sınırların tartışmalara yol açacak şekilde çizilmesi ve sorunlu bölgeler oluşturulmasıyla, binlerce yıldan beri birlikte yaşayan Müslüman Türk veya Müslüman Türk olmayan halkların, farklı ulus devletlere dağıtılarak, birçok açıdan bölerek çatıştırmayı ve kargaşayı sürekli kılma hedeflenmiştir. Tarihi ve kültürel bir temeli olmadığ1 halde 1920'lerde oluşturulan bu kargaşa alanlarının, günümüzde de uzlaşmazlık, gerginlik ve istikrarsızlık nedeni olması, tesadüfi değildir. Örneğin Kırgızistan'ın Soh anklavında yaşayan halk etnik olarak Tacik olduğu halde Özbekistan'ın egemenliğine bırakılmıştır (İmamova, 2014). Dolayısıyla Soh, Kırgızistan sınırları içinde olduğu halde Özbekistan açısından egemenlik, Tacikistan açısından soydaşlık sorununa kaynaklık etmektedir.

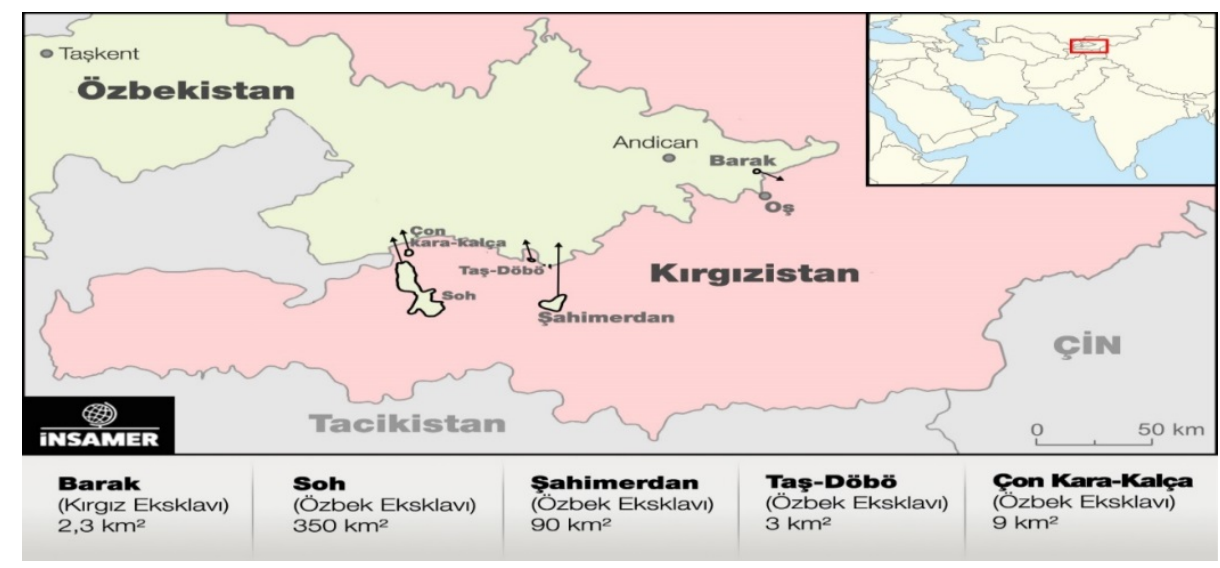

Harita 2. Özbekistan ve Kırğı̨istan Simurlar İçindeki Anklav/Ekslavlar (Çalışkan, 2019)

\footnotetext{
${ }^{4}$ Yukarıda işaret edilen gerekçelerle Tacikistan'ın bu ülkelerle anklav/eksklavları burada yer almamaktadır.
} 


\section{Özbekistan'da Yeni Dönem ile Başlayan Çözüm Süreci}

14 Aralık 2016'da Şevket Mirziyoyev, Özbekistan'ın yeni cumhurbaşkanı oldu. Mirziyoyev yönetimi, komşularla önemli ölçüde kesilmiş olan ilişkileri yeniden tesis ederek her komşu devlete resmi ziyaret düzenledi. Bu ziyaretler esnasında ele alınan konular arasında dostluk, ekonomik işbirliği antlaşmaları ve ülkeler arasında uzlaşmazlık sebebi olan hudut problemlerinin çözümü yer aldı. Böylece köklü ve güven verici ilişkilerin kurulması için gayret sarf etti. Bu ziyaretlerden birini 5 Eylül 2017'de Kırgızistan'a düzenledi. Böylece Özbekistan ve Kırgızistan liderleri Bişkek'te bir araya gelerek ilk temas geçekleşmiş oldu. Haberler, Cengiz Aytmatov'un eserindeki "Devlet sınırlarılya ilgili antlaşmalar, siyasi irade ve uzlaşmadır", "Antlaşma yapılabilir mi?" benzeri başlıklarla verildi. Görüşmelerde Özbekistan ve Kırgızistan arasında kesinleşmemiş sınırlar ele alındı ve bu sınırların \%85'i konusunda antlaşmalar imzalandı. Bu resmi ziyarette toplam 12 antlaşma imzalanmış olup bunlardan biri de "Kırgızistan Cumhuriyeti Hükümeti ile Özbekistan Cumhuriyeti Hükümeti Arasında Sınır Temsilcilerinin Faaliyetleri Hakkında Antlaşma"dır (Kırgizistan ve Özbekistan Devletleri Sınır Anlaşması, 2017).

Özbekistan Başbakanı Abdulla Aripov'un, 1 Ağustos 2018'de Bişkek'i ziyaretiyle sınırlar sorununun çözümü konusunda yeni gelişmeler yaşandı. Bu ziyarette alınan kararlar sonucu sınırlar konusundaki uzlaşmazlıkarın \%92'si çözülmüss oldu (Özbekistan Cumhuriyeti Başbakan1, 2019). Bu görüşme ile, Kırgızistan Cumhurbaşkanı, Kırgızistan'ın Özbekistan'daki Barak eksklavı konusunda arazi takası yaparak uzlaşma kararı aldı. Yukarıda belirtilen Hükümetlerarası Komisyonun Oş Bölgesi üyesi Bayysh Yusupov, 14 Ağustos 2018'de yaptığı açıklamada Barak eksklavı konusundaki kararın netleştiğini, Barak karşıllğında sınır bölgesinde verimli toprakların Kırgızistan'a takas edileceğini açıklamıştır (Kırgızistan ve Özbekistan Sınır Topraklarını Değiştirmeyi Kabul Etti, 2018). Bu karar ile Kırgızistan'a ait Barak eksklavı Özbekistan'a bırakılacak, Özbeksitan, Oş bölgesindeki Ak-taş köyü ile sınırdaş olan Birleshken köyünden, eşit ölçüde toprağı Kırgızistan'a vermiş olacaktır (Krivoşeev ve Karabekov, 2018). Komisyon tarafından Barak bölgesi kapsamındaki değişim için ayrıntılı sınırlandırma ve takas çalışmaları yapılmıs, Komisyon üyeleri gerekli protokollerin tamamlanması sürecindeki anlaşmaları imzalamışıtı. Fakat yapılan anlaşmaların yürürlüğe girmesi için, bu anlaşmaların her iki ülke cumhurbaşkanları tarafindan imzalanması beklenmektedir (Kırgizistan Barak Bölgesini Özbekistan'a Verecek, 2018). Mayıs 2020 itibariyle bu mutabakat metinleri cumhurbaşkanları tarafindan henüz imzalanmamıştır.

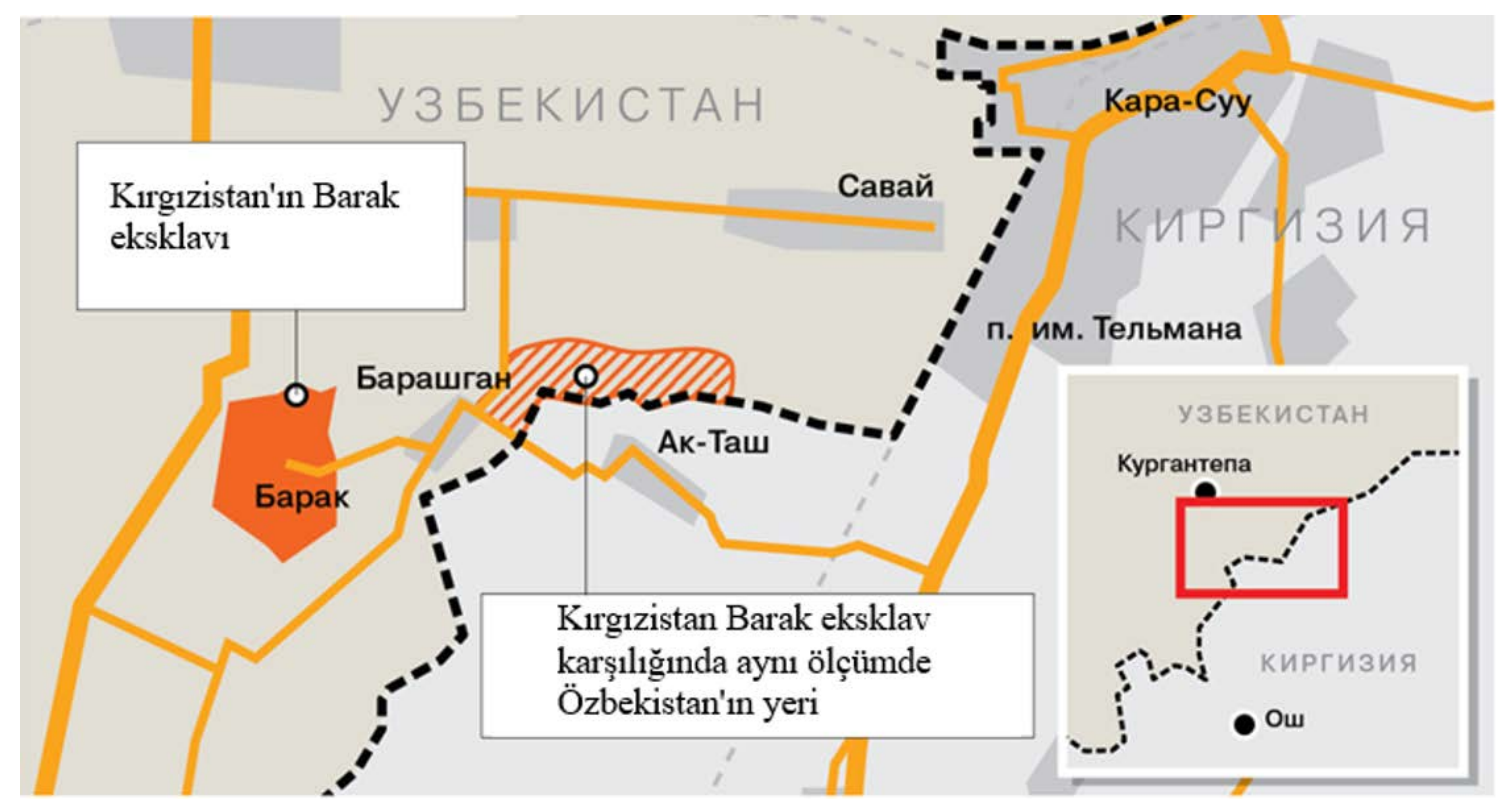

Harita 3. Özbekistan ve Kirgızistan Toprak Takas Bölgesi

\section{Sorun Çözümü ve Diplomasi Kültürü}

Devletler tarihiyle birlikte komşu ülkeler arasındaki sınır sorunlarının eksik olmadığı bilinmektedir. Klasik dönemde "kuvvet haktır" prensibi gereği güçlü olan taraf, istediğini elde edebilirdi. Bununla beraber klasik dönemde de birçok savaşın galiplerinin kazandıkları, kaybettiklerinden çok daha az olabilmiştir. Siyasi literatüre "Pirüs Zaferi" olarak geçen kavram, güçlü taraf her ne kadar galip gelmiş olsa da kaybettikleri yanında kazandıklarının anlamsız kalması demektir. Buna karşın sorunların çatışma yerine 
diplomasi ve başta Uluslararası Hukuk yolları olmak üzere barışçıl mekanizmalarla çözülmesi, bütün tarafların çıkarına olan yöntemdir.

I. ve II. Dünya Savaşlarından sonra, savaşları önlemek, ülkeler arasındaki sorunları barışçl yollarla çözmek üzere birçok sözleşmeler imzalanmış, kurallar ve örgütler oluşturulmuştur. Bununla beraber özellikle eski sömürgeciler, sömürüyü devam ettirmek maksadıyla bağımsızlğıını kazanan devletlere birçok sorunlar bırakmışlar, bağımsızlık sonrasında da bu sorunların çözülmesini engellemek üzere mekanizmalar geliştirmişlerdir. Günümüzde de genellikle gelişmiş, batılı ülkeler hedef ülkeleri kontrol etmek üzere komşular arasında sorunları kışkırtmak, yeni sorun konuları oluşturmak, bir şekilde hedef devletlerin ve halkların işbirliğini önlemek üzere birçok stratejiler uygulamaktadırlar (Canbolat, 2004, s. 39). Buna karşın yeni bağımsız devletler arasında da komşularla çatışma tuzağına düşmeden, eski sömürgecilerin tuzaklarını bir şekilde aşarak komşularıyla güven ve işbirliğine dayalı ilişki kurmayı başaran örnekler de bulunmaktadır.

Özbekistan'da Mirziyoyev dönemiyle birlikte komşularla ilişkileri geliştirme, muhtemel çatışma konusu olabilecek sınır ve diğer sorunları çözme yönünde irade ortaya konmuştur. Barak konusundaki Kırgızistan ile yapılan mutabakat bu anlamda önemli bir gelişme olmasına karşın Mayıs 2020 itibariyle bunun henüz yürürlüğe girmediği görülmektedir. Bunun yanında Kırkızistan'daki Özbekistan eksklavları konusunda da çözüm iradesi ortaya konduğu halde henüz ayrıntılı mutabakata varılmamıştır. Öte yandan Kırgızistan, Özbekistan ve Tacikistan'ın Fergana bölgesindeki harita, coğrafi olarak son derece sorunlu olduğu gibi etnik yapı açısından da söz konusu ülkeler arasında uzlaşmazlık veya çatışma alanları kurma açısından ilginç özelliklere sahiptir. Dolayısıyla eksklav ve anklav sorunlarının çözülmesinden sonra sınır düzenlemeleri günümüz şartlarında zor olsa da bölge halklarının ticaret, eğitim, ziyaret, tedavi gibi amaçlarla seyahatlerinin kolaylaştırılmasın ihtiyaç duyulmaktadır. Sovyet döneminde sınırların çizilmesindeki kötü niyet çerçevesinde bu tür seyahatler oldukça zorlaştırılmış ve sorunlu hale getirilmiştir. $\mathrm{Bu}$ gerçekler dikkate alınarak söz konusu ülkeler arasında Serbest Ticaret Bölgesi veya vizesiz seyahat benzeri anlaşmalara giden süreçler de başlatılabilir.

Mevcut şartlar altında sorunların çözümünde öncelikle doğrudan iki ülkenin diplomasi yolunu tercih etmesi son derece önemli olup Barak girişiminde bu süreç başlatılmıştır. Bununla beraber diplomatik müzakerelerde tarafların azamisini alma hedefi, bir taraf tatmin olurken diğer tarafın kaybetmiş taraf durumuna düşmesinin kamuoyu veya muhalefet unsurları açısından sorunlara yol açtığ1 görülmektedir. Mesela Yusupov'un yukarıda aktarılan, Kırgızistan'ın egemenliği altındaki Barak'ı Özbekistan'a bırakması karşlığında sınır bölgesinde verimli topraklara sahip olacağı beyanı, Kırgızistan kamuoyu açısından memnuniyet sebebi olmasına karşın Özbekistan'da sıkıntılara yol açma ihtimali bulunmaktadır. Türkçe literatürde de "çakıl taşı" hassasiyeti, ülke egemenliğindeki toprakların bir başka ülkeye verilmemesi gerektiği yönünde baskı kaynağı olabilmektedir. Her ne kadar geleneksel devlet kimliği ile vatan toprağının kutsallığ tartışılmaz ise de günümüz şartlarında ülkenin huzuruna, refahına kasteden bu tuzak uygulamaların bir an önce sona erdirilmesi yönünde kamuoyunun hazırlanması son derece önemlidir.

Özbekistan ve Kırgızistan başta olmak üzere bölge ülkeler arasındaki sorunlu alan ve sınırların öncelikle ilgili ülkeler arasında çözülmesi sürecinde yöneticiler açısından muhalefet, kanaat önderleri, akademik çevreler, medya ile dost ülkelerin de işbirliği ve desteği gereklidir. Aksi takdirde bugün yapılan bir mutabakatın uygulama aşamalarında yönetim değiştiğinde aksamaya uğrama ihtimali bulunmaktadır. Fakat milli mutabakat ile toplumun bütün kesimlerinin desteğinin alındığı bir düzenlemenin başarılı olma şansı yüksektir.

Uyuşmazlığın taraflarının kendi rızalarıyla hakeme başvurmaları, Uluslararası Hukuk alanında birçok sorunun çözümünde etkili ve barışçıl yöntemlerdendir. Türk cumhuriyetleri arasındaki sorunların çözümünde ikili müzakereler yanında başta Türk Keneşi olmak üzere dost ve soydaş ülkeler arasındaki ortak zeminlerden de yararlanmak mümkündür. Gerektiğinde arabulucu heyetler veya süreçler oluşturularak, çözüm sürecinde çok daha geniş bir destek sağlanabilir. Bu tür zeminlerin genel hakemlik özelliği yanında, çözümün kalıcı olması ile garantörlük veya izleme fonksiyonları, bütün taraflar için, özellikle risk alma durumundaki yöneticiler için önemlidir. Her ne kadar sorunların çözümünde örneğin Özbekistan ve Kırgızistan yöneticilerinin doğrudan ortak mutabakatı yeterli ise de iç ve dış kışkırtmalar veya doğal muhalefet süreci açısından tarafsız bir kişi, heyet veya kuruma havale kararı ile verilecek kararı peşinen kabullenme medeni devlet geleneğinin de bir gereğidir (Doğan, 2016, s. 453). 


\section{Sonuç ve Öneriler}

Avrupa'da feodalitenin çözülmesi sürecinde ortaya çıkan imparatorluklar döneminde, küçük devletlerin ve azınlıkların sömürülmesi, toplumun çoğunluğunu oluşturan halklara yönelik baskı ve şiddet sonucu ortaya çıkan isyanlar ve ihtilaller ertesinde ulus devletlerin oluşum süreci başlamıştır. Önce Fransız ihtilali ile başlayan ulus devlet hareketi, bir süre sonra bütün Avrupa'yı hatta dünyanın birçok bölgesini etkilemiş, her milletin kendi devletini kurma fikri yaygınlık kazanmıştır. Sonraki aşamada ise sömürgeci devletlere karşı kendi ulus devletini inşa hareketi, bir anlamda sömürüye karşı bir kale hale haline gelmiştir. Buna karşın sömürgeci vasıfları bulunmayan, yönettiği halklara adalet, huzur ve refah götüren Osmanlı ve Türkistan hanlıkları, bu dönemde yıkılma sürecine girmiştir. Bu devletlerin yıkılması ve ulus devletler haline gelerek parçalanması sonucu, batılı sömürgecilerin emperyalizm politikaları, daha kolay uygulama alanı bulmuştur. Osmanlı'dan ayrılan coğrafyadaki devletlere Batı emperyalizmi, Türkistan hanlıkları bölgesindeki halklara ise Bolşeviklerin kurduğu SSCB sistemi hâkim olmuştur.

Bolşeviklerin Türkistan hanlıklarında yaşayan Müslüman halkı, mensup oldukları boylarına göre ayrı millet muamelesi yapmasıyla farklı devlet sınırları çizilmiş ve birbiriyle çatışan birçok ulusun ortaya çıkması sağlanmıştır. Bolşeviklerin çatışma ve gerginliği sürekli kılma hedefine dayanarak çizdiği sınırlar halen geçerli olup uzlaşmazlık kaynağı fonksiyonunu yerine getirmektedir. Bölge halkları ve bu halkların oluşturduğu devletler, barış, huzur ve güvenlik içinde işbirliğini geliştirerek medeniyet ve refahı ilerletmek yerine, sınırları ve egemenlik alanları kapsamında anlaşmazlıklar, zaman zaman çatışma aşamasına gelen krizlerle meşgul olmak zorunda kalmışlardır. Bu bağlamda Bolşevik yönetimince oluşturulan anklav/eksklav temelli sorunlar hemen bütün Türk cumhuriyetlerinin huzur, refah ve güvenliği için tehdit oluşturmaya devam etmektedir. SSCB dağıldıktan sonra anklav/eksklav temelli sorunlar, bağımsız Türk devletleri arasındaki gerginliği sürekli kılmaya adaydır. Özellikle Özbekistan ve Kırgızistan arasındaki uyuşmazlık, yaklaşık çeyrek asır boyunca ciddi krizlere sebep olmuş, halk bundan büyük zarar görmüştür. Bu konuda çözüm konusunda bazı girişimler olmuşsa de sorun henüz bütünüyle çözülmemiştir.

Özbekistan'ın 2016'da seçilen cumhurbaşkanı Mirziyoyev, komşu cumhuriyetlerle dostluk anlaşmaları imzalayarak sorunları çözme, işbirliğini geliştirme yönünde ciddi girişimler başlatmıştır. Bu kapsamda Kırgızistan ile anklav/eksklav alanları için çözüm süreci başlamıştır. İki devlet ve halklar arasındaki barış ve işbirliği için bu sorunların karşılıklı rıza, güven ile hukuk ve hakkaniyet çerçevesinde çözülmesi, çözüm sürecinde gerekirse Türk Keneşi gibi kurumların hakemliğine gidilmesi, bu çözüm sürecinin diğer ülkelere de örnek olması beklenmektedir. Bu anlaşmazlık yüzünden hemen her yll asker kaybı olmakta, öncelikle bu bölgelerde yaşayan halkların vatandaşı olan devletlerle ilişkilerinde, eğitim, sağlık ve çalışma hayatlarında büyük zorluklar yaşadığı bilinmektedir. Bu durum, Kırgız halkı veya Özbek halkının huzur ve refahını olumsuz etkilediği gibi benzer sıkıntılar, zaman zaman çatışmaya giden sorunlar, diğer bölge ülkeleri için de varlığını sürdürmektedir. Binlerce yıldır aynı coğrafyayı paylaşan, aynı devlet çatısı alında yaşamış olan bu kardeş halkların önceki hataları tekrar etmemesi yönünde iktidar, muhalefet, sivil toplum kuruluşları, akademik birimler, medya ve aydınlar ile Türk dünyasının diğer kurumlarına ve fikir önderlerine önemli görevler düşmektedir. Bu çalışmanın sonucu olarak sorun çözümünde şu öneriler sunulmaktadır:

- Anklav ve ekslav uygulamaları, örneğin 3 yıllık bir süre içinde karşılıklı olarak sonlandırılır;

- Her ülke sınırları içinde diğer ülkenin egemenlik bölgesindeki alana karşllk diğer ülke sınır bölgesinde alternatif alanlar sunularak, önerilen alanların özelliğine göre belirli müzakere ve uzlaşma ile toprak takasları yapılır;

- Ülkelerin karşlıklı olarak anklav/eksklav bölgeleri varsa takas sürecinde öncelikle bunlar kapatılır; her devlet kendi bölgesindeki anklav alanına egemen olur;

- Sözkonusu bölgede yaşayanların vatandaşlıkları konusu, öncelikle bu kişilerin tercihine bırakılabilir, geçici olarak veya bir nesil için çifte vatandaşlık hakkı verilir;

- Diğer ülkeye geçmek isteyenlerin mülklerinin karşılığını veya mal varlıklarını, kendi ülkesine taşımak için her türlü kolaylık sağlanır;

- Takas edilecek toprakların özelliği ve diğer ayrıntılar konusunda, üyeleri ilgili ülkelerin onayı ile uzmanlardan oluşturulmuş örneğin Türk Keneşi bünyesindeki bir hakemlik birimi son kararı verir;

- Gerek ikili gerek çok taraflı mutabakatlar sonrası kamuoyu bilgilendirmeleri konusunda da ilgili taraflarca ortak metin hazırlanır; bir taraf kendi kamuoyunu memnun etmek üzere beyanatta bulunurken diğer hükümeti zor durumda bırakabilecek ifadelerden kaçınır; 
- Mevcut durumun muhtemel uzlaşmazlık ve çatışma ile refah ve huzuru bozucu olduğu, bir tarafin mağdur olduğu çözümün dahi bütün taraflar için şu andakinden çok daha yararlı olacağ1 gerçeği konusunda ilgili ülkelerin kamuoyunun aydınlatılması için yaygın bilgilendirme çalısmaları yapillr.

\section{Etik Beyan}

"Özbekistan ve Kırgrzistan'daki Anklav/Ekesklav Alanlarnmn Çöఇüm Süreci” başlıklı çalışmanın yazım sürecinde bilimsel, etik ve alıntı kurallarına uyulmuş; toplanan veriler üzerinde herhangi bir tahrifat yapılmamış ve bu çalışma herhangi başka bir akademik yayın ortamına değerlendirme için gönderilmemiştir” şeklinde bir ibare eklenmelidir.

\section{Kaynakça}

Akınc1, A. (2012). Modern ulus devletlerin doğuşu. Dumlupinar Üniversitesi Sosyal Bilimler Dergisi, 34, 61-70.

Alamanov, S. (2018). Orta Asya Anklav Sorununun Tarihi ve Güncel Sorunları, Bishkek. Саламат А^аманов, Анклавы в Центральной Азии История Вопроса и Современные Проблемы, Бишкек. https://cyberleninka.ru/article/n/anklavy-v-tsentralnoy-azii-istoriya-voprosa-i-sovremennye-problemy/viewer. Ay, H. ve Uçar, Ö. (2015). Devletin gelişim süreci. Dokuz Eylïl Üniversittesi, İsletme Fakültesi Dergisi, 16(2), 195-206.

Barthold, W. (1902). Turkistan. Entsiklopedigeskiy Slovar, 174-204. Petersburg.

Bilsel, C. (1940). Devletter bukuku (2. Baskı). İstanbul Üniversitesi Yayınları.

Canbolat, İ.S. (2004). Gelismekte olan ülkeler: Küresel, politike ve ekonomik şıar iliskilerindeki konumlar. İstanbul: Aktüel.

Çalışkan, B. (2019). Özbekistan ve Kırgızistan Arasındaki Problemleri Çözmek Mümkün mü? https://insamer.com/tr/ozbekistan-ve-kirgizistan-arasindaki-sinir-problemlerini-cozmek-mumkunmu_1918.html

Demir, T. (2013). Afrika sömürge mücadelelerinin sıradıșı coğrafi fragmanların oluşumundaki etkisi. İ.Ü. Edebiyat Fakültesi Coğrafya Bölümü Coğrafja Dergisi, 26, 76-93.

Demir, T. (2019). Kolonyal dönemden günümüze jeopolitik bağlamda anklav/eksklav ïlke topraklar-güvenlik ilişkisi. Ankara: Nobel Akademik Yayıncilik.

Devlet, N. (1989). Cağdaş Türk dünyası. İstanbul: Marmara Üniversitesi Yayınları.

Doğan, İ. (2016). Devlettler bukuku (3. Baskı). Ankara: Astana Yayınları.

Dupuy, R.J. (1990). Uluslararası bukuk (Çev: S. Bağdatlı). İstanbul: İletişim Yayınları.

Eşov, B. (2012). Türkistan Özerk Sovyet Cumhuriyeti. Боходир Эшов, Туркистон Автоном Совет Республликаси (Туркистон Республиикаси). http://shosh.uz/turkiston-avtonom-sovet-respublikasi-turkiston-respublikasi/.

Evans, G. ve Newnham, J. (2007). Sinır. Uluslararast İliskiler Sözliugüu (Çev: Utku, H.A.). İstanbul: Gökkubbe Yayınları.

Göze, A. (1959). Devletin ülke unsuru: Simrlar ve devletle olan münasaebetleri (Doktora Tezi). İstanbul Üniversitesi, Hukuk Fakültesi.

Gözler, K. (2007). Devletin genel teorisi (10. Baskı). Bursa: Ekin Yayınları.

Gündüz, A. (2003). Milletlerarası bukuk: Temel belgeler, örnek kararlar (5. Baski). İstanbul: Beta.

Hayit, B. (1988). Türkistan terimi üzerine. Türk Dïnyasi Arasttrmalar Dergisi, 53, 23-34.

İmamova, N. (2014). Farg'ona Vodiysidagi Anklav-Eksklavlarda Vaziyat Qanday? Amerika Ovoz1 VOL, https://www.amerikaovozi.com/a/enclaves-central-asia-fergana-valley-/2546448.html.

İmankulov, М. (2014). Krrg̨zistan Taribi (XX-XXI yу.). Bişkek. Муратбек Иманкулов, История Кыргъззстана (XXXXI вв.), Бишкек.

Kırgızistan ve Özbekistan Devletleri Sınır Anlaşması İmzaladı (2017). Международный Научно-Оббщественный Журнал "Мир Перемен", http://mirperemen.net/2017/09/kirgiziya-i-uzbekistan-zaklyuchili-dogovor-ogosudarstvennoj-granice/.

Kirgizistan ve Özbekistan İlişkileri (2015). Взаимоотношения межАу Кыргызстаном и Узбекистаном, $\quad$ https://stanradar.com/news/full/18347-vzaimootnoshenija-mezhdu-kyrgyzstanom-iuzbekistanom.html

Kırgızistan ve Özbekistan Sınır Topraklarını Değiştirmeyi Kabul Etti (2018). Interfax-Azerbaijan, Киргизия и Узбекистан Аоговорились обменяться приграничными земельными участками, http://interfax.az/view/741241.

Kirgizistan, Barak Bölgesini Özbekistan'a Verecek (2018). https://www.fergananews.com/news/31999.

Kotan, C. (2016). Modern Dünya Sistemi Teorisi Bağlamında Modern Devletin Özellikleri. Uluslararası Politile Arastirmalar Dergisi, 2 (1), 11-25.

Krivoşeev, K. ve Karabekov, K. (2018). Kırgızistan ve Özbekistan Bölgeleri Değiştirilebilir. Кирим^ Кривошеев и Кабай Карабеков, АО «Коммерсанть», Киргизия и Узбекистан могут поменяться территориями, Бишкек, https://www.kommersant.ru/doc/3714329

Mirow, M.C. (2010). The Social-Obligation Norm of Property: Duguit, Hayem, and Others. Florida International University College of Law. 
Orta Asya Jeopolitiği ve Bölgenin Ekonomisi (2010). Stratejik Değerlendirme ve Analiz Enstitüsü. Moskova. Центральная Азия. Геополитика и Экономика Региона. Институт Стратегических Оценок и Анализа (ИСОА), Москва, 2010, http://www.isoa.ru/docs/central_asia-book.pdf.

Özbekistan Cumhuriyeti Başbakanı, Kırgızistan Başkanı Sooronbay Jeenbekov ile Görüşecek (2019). Новостное агентство Спутник, "Премьер-министр РУз проведет переговоры с президентом Кыргызстана Сооронбаем Жээнбековым, https://uz.sputniknews.ru/politics/20190801/12137957/Abdulla-Aripovposeschaet-s-rabochim-vizitom-Kyrgyzstan.html

Özdemir, H. ve Bakan, S. (2016). Ulus Devletin Oluşumu ve Sorunları Açısından Almanya ile Fransa'nın Karşılaştırılması. Bitlis Eren Üniversitesi Sosyal Bilimler Dergisi, 5 (Ek Say1), 19-58.

Rajabov, Q. ve Zamonov, A. (2017). O'zbekiston Tarixi. Taşkent: G'afur G'ulom Nashriyot.

Strong, J.W. (1975). The Ignat'ev Mission to Khiva and Bukhara in 1858. Canadian Slavonic Papers, 17 (2-3), $236-260$.

Usmonov, Q., Sodıqow, M., ve Burxonova, S. (2006). O'žbekiston tarixi. Taşkent: İktsod-Moliya

Usmonov, Q., Sodiqow, M. (2010). O'žbekiston tarixi (1917-1991 yillar). Taşkent: Bosh Neşriyatı.

Waltz, Kenneth N. (2015). Uluslararası politika teorisi (Çev: O. S. Binatlı Edt: Ç. Özen). Ankara: Phoenix.

Yalçınkaya, A. (1997). The Frontiers of Turkestan. Central Asian Survey, 16 (3), 431-438.

Yalçınkaya, A. (2004). Yetmis yallık keriz: Sovyetler Birliŭìnde Moskova-Türkler ilișkileri (3. Baskı). İstanbul: Beta.

Yalçınkaya, A. (2006). Sömürgecilik Pan-İslamiz̨m Isı̆ğında Türkistan (2. Baskı). Ankara: Lalezar Kitabevi.

\section{EXTENDED ABSTRACT}

The concept of nations as the founding element of the state emerged in French Revolution process and became the main element of the transformation of states from dynasty identity to nations-state form. In this process, the kingdoms of Western Europe left their power to the representatives of the people. Thus the concept of nation expressed the unity of communities that shared the same fate rather than an ethnic identity, who had the same suffering and trouble before, and that hope to be a peaceful and prosperous society together in the future. On the other hand, nationalization processes based on ethnic origin, religion, sect or tribal foundations in the old colonies formed the basis of identity.

This article summarizes the historical process in the emergence of nation states. In this context, within the scope of International Law, the methods of earning and losing land based on mutual agreements with other state/states regarding the country of the state are touched. Within the scope of the country of the state, the definition of the enclave/exclave regions belonging to one state but within the borders of the other state is given and the problems and conflicts arising from this application are touched. After the First World War independent states were established with the collapse of the Tsarist regime. With the Bolsheviks taking over the region again, nation states based on ethnic groups or tribes were formed and borders were determined. After the Turkestan khanates, the creation of tribal-based republics is summarized in the example of Uzbekistan and Kyrgyzstan. Legal arrangements and international agreements in the process of establishing and borders of these states are explained. Finally, the problems arising from their country territory and borders are mentioned. In this context, problems related to enclave/exclave areas in both states and developments with the scope of the solution are touched and suggestions are presented.

On December 14, 2016, Shavkat Mirziyoyev became the new President of Uzbekistan. The Mirziyoyev administration reestablished relationships with neighbors, re-organizing official visits to each neighboring state. The topics addressed during these visits included friendship, economic cooperation treaties, and the solution of border problems that were the cause of disagreement between countries. $\mathrm{He}$ organized one of these visits to Kyrgyzstan on September 5, 2017. During the talks, uncertain borders between two countries were addressed, and treaties were signed on $85 \%$ of these borders. With the subsequent contracts, a land swap decision was taken on the Barak exclave of Kyrgyzstan in Uzbekistan. Thus, the Barak exclave of Kyrgyzstan will be left to Uzbekistan, and the Uzbekistan will give the soil to Kyrgyzstan equally from the village of Birleshken, bordering the Ak-Tash village in the Osh region. Similar protocols were signed for other areas. However, for the agreements to come into force, these agreements are expected to be signed by the presidents of both countries. As of May 2020, these reconciliation texts have not yet been signed by the presidents.

After World Wars, many conventions were signed and rules and international organizations were created to prevent wars and solve problems between countries peacefully. However, especially the former colonists left many problems to the states that gained their independence in order to continue the exploitation. Today, mostly developed, western countries implement many strategies to control the target countries, to provoke problems among neighbors, to create new problems issues and to prevent cooperation of target states and peoples. On the other hands, there are also examples among the new 
independent states that have succeeded in establishing trust and cooperation with their neighbors by overcoming the traps of the old colonists without falling into the trap of neighbors. It is extremely important that the new independent republics, who know these facts very well, may solve these area and border problems peacefully.

In the process of resolving the problematic areas and boundaries between the countries in the region, especially in Uzbekistan and Kyrgyzstan, the cooperation and support of the opposition parties, opinion leaders, academic circles, media and friendly countries are also required for administrators. Otherwise there is a possibility that a reconciliation made today will be disrupted when management changes. However, an arrangement in which the support of all segments of the society is obtained with the national consensus has a high chance of success. As a result of this study, the following suggestions are offered in problem solving:

- Enclave and exclave applications should be mutually terminated, for example over a period of 3 years;

- In the boundaries of each country, alternative areas are offered in the borders region of the other country; according to the characteristics of the proposed areas, soil exchange is made with certain negotiations and reconciliation;

- If the countries have mutual enclave/exclave areas, they are primarily exchanged during the solution process;

- The subject of citizenship of those living in these areas in question can be left to the preference of those people, and the right to dual citizenship may be granted temporarily or for a generation;

- All kinds of facilities are provided for those who want to move to another country to move their property price or assets to their country;

- On the characteristics of the land to be exchanged and other details, a refereeing unit within the Turkic Council (Türk Keneşi), whose members have been formed by experts with the approval of the relevant countries, makes the final decision;

- A common text is prepared on informing the public after bilateral and multilateral agreements; while one side makes a statement to please its public, it also must avoid statements that will put the other government in a difficult position;

- Extensive information activities are carried out to inform the public about the fact the current situation is possible discord and conflict, and that the solution to the welfare and peace, and even the solution to which one side is a victim will be much more beneficial than the present order. 